\title{
Sanitation Mapping of Groundwater Contamination in a Rural Village of India
}

\author{
P. U. Megha1, P. Kavya1, S. Murugan'2, P. S. Harikumar' \\ ${ }^{1}$ Water Quality Division, Centre for Water Resources Development and Management, Kozhikode, India \\ ${ }^{2}$ Department of Biotechnology, School of Biotechnology and Health Sciences, Karunya University, Coimbatore, \\ India \\ Email: hps@cwrdm.org
}

Received 19 December 2014; accepted 4 January 2015; published 14 January 2015

Copyright (C) 2015 by authors and Scientific Research Publishing Inc.

This work is licensed under the Creative Commons Attribution International License (CC BY).

http://creativecommons.org/licenses/by/4.0/

(c) (i) Open Access

\section{Abstract}

Availability of clean water and adequate sanitation facilities are of prime importance for limiting diarrheal diseases. We examined the spatial information on the groundwater quality and sanitation facilities of a village in southern India using Geographic Information System (GIS) tools. Place of residence, position of wells and latrines were mapped and well water samples were tested for microbial contamination (Total Coliform Counts (TCC), Fecal Coliform Counts (FCC) and Fecal Streptococcal Counts (FSC)). A well structured questionnaire was administered to 50 residents of the selected areas to elicit information on water collection, handling and storage. The location and distances of wells from latrines were determined using the Global Positioning System (GPS) device and a tape rule respectively. Data on 170 cases of various water-borne diseases were collected from primary health centers in the study area. Groundwater in the village was found to be microbiologically unfit for consumption. Analysis using direct observations supplemented by GIS maps revealed poor planning, design of the wells and improper siting of wells from latrines which were found to be the possible reasons of groundwater contamination. There was a significant difference in TCC between covered and uncovered wells $(p<0.01)$ but no significant differences were observed in the FCC, FSC and well covering. The mean distance $(6.44 \pm 2.37 \mathrm{~m})$ of wells from the latrines in the study area was below the limit $(15.24 \mathrm{~m}$ or $50 \mathrm{ft})$ set by United State Environmental Protection Agency (USEPA). TCC and FCC increased with a decrease in distance between the wells and latrines with a significance $(p<0.01)$. A moderate negative correlation $(r=-0.593, r=-0.470)$ was ensued between the distance from latrine and coliform count. This study accentuates the need to set standards for the siting of wells from latrines and need for treatment.

\section{Keywords}

Geographic Information Systems, Sanitation, Groundwater, Latrines, Microbial Count 


\section{Introduction}

There is a growing concern throughout India about the contamination of groundwater as a result of geogenic and human activities. In India, groundwater resources are being utilized for drinking, irrigation and industrial purposes. The groundwater is estimated to provide about 80 percent of water for domestic use in rural areas and about 50 percent of water for urban and industrial areas. With the rapid growth in population, urbanization, industrialization and other developmental activities, groundwater resources have become vulnerable to depletion and quality degradation. Wells are a common groundwater source readily explored to meet community water requirement or make up the short fall [1]. Kerala is strongly dependent upon groundwater and has considerable value both for its economic and social uses.

Open dug wells are important groundwater extraction structures in the coastal belt of Kerala and groundwater is the most common source of drinking water in these areas. Of late, these precious resources are getting contaminated by various contaminants and anthropogenic activities. Open wells of Kerala have the problem of bacteriological contamination and a study conducted by Centre for Water Resources Development and Management (CWRDM), Kozhikode indicates that $70 \%$ of the drinking water wells have fecal contamination [2]. This could be due to poor or poorly maintained sanitation facilities. The cause of contamination is attributed to close proximity of latrines to wells, unhygienic usage of the wells (e.g. some wells have no cover/lids; they are dirty and unkempt) thus, making the water unfit for use, resulting into water borne disease.

Safe drinking water remains inaccessible for about 1.1 billion people in the world [3]. Those most susceptible to water borne illnesses are children, the elderly, pregnant women and immunocompromised individuals, making water-borne illnesses one of the five leading causes of death among children under age five [4]. In 1997, the World Health Organization (WHO) reported that $40 \%$ of deaths in developing countries occur due to infections from water related diseases and an estimated 500 million cases of diarrhea, occurs every year in children below 5 years in parts of Asia, Africa and Latin America [5]. Drawing from the observations made by [6] to that of [7], it is clear that the environmental factor "water" and the problem of water borne diseases, especially diarrhoeal diseases are linked up via two different mechanisms; through the supply of contaminated water and or lack of water for personal hygiene.

Kodiyathur Village of Kozhikode district, Kerala suffers serious water problems. Potable water is one that should not contain chemical substances or microorganisms in amount that can cause hazards to health [8]. Water must be substantially free of dissolved salts, plant, animal waste and bacterial contamination to be suitable for human consumption. Poorly designed latrines and inadequately maintained septic systems can contaminate ground water with nitrates, bacteria and toxic cleaning agents. This can serve as a vehicle for spreading illnesses caused by microorganisms such as; Vibrio cholera, Yersinia enterocolitica, Escherichia coli, Cryptosporidium spp. and vector borne diseases such as guinea worm, Schistosomiasis, lymphatic filariasis, Onchocerciasis, parasitic and viral infections [7] [9]. Fecal [10]-[12] and chemical (from industries and farms) contamination, combined with the failure to adequately treat water, have been incriminated in many water borne epidemics [13].

In Kodiyathur Village, there is a challenge of lack of protected water supply hence many homes have wells situated around the house near the latrine. For most communities, the major source of safe drinking water is piped water supplied from municipal water treatment plants. Often, most of water treatment facilities could not deliver or fail to meet the water requirements of the served community due to lack of infrastructure, lack of maintenance or increased population. The scarcity of treated water has made communities to find alternative sources of water that is groundwater sources being a ready source. Hence, the need to ensure the supply of potable water is a priority to the prevention of water borne illnesses. The increasing dependence on ground water as a source of potable water has spurred efforts to protect the quality of this limited resource.

It has been estimated that the total volume of waste disposed off via latrines is approximately 800 million gallons per year, virtually all of which is disposed in the subsurface [14]. This makes latrines the leading contributor to the total volume of waste discharged directly to groundwater. Assessment of water is therefore very crucial to safeguard public health and the environment [15]. Climatic conditions, land use patterns, vegetative cover, topography, soil and geologic characteristics, well condition, location of potential pollution sources, and agricultural management practices can affect the transport and contamination of groundwater by bacteria [16]. Both fecal coliform and fecal streptococci bacteria are present in the gastrointestinal tract of humans and other warm-blooded animals. The presence of these bacteria in natural water indicates degradation by human or ani- 
mal waste and may be related to septic-tank waste.

It is noteworthy that individual houses in Kodiyathur Village, are closely packed with a total of 6181 houses in an area of $29.9 \mathrm{sq} \cdot \mathrm{km}$. The total population of the study area is 26,429. Refuse dumps, pit latrines and open sewers are common and environmental sanitation is a negligible component in the area. All these suggest possible chances of pollutants and contaminants entering these wells. Improving the quality of groundwater resources offers an important economic opportunity for the gradual improvement of the quality of life [17]. Therefore, evaluation of the microbial quality of water is an important weapon to the achievement of potable water for daily consumption.

This study aims to assess the bacteriological quality of groundwater at Kodiyathur Village using the microbial counts (total coliform, fecal coliform and fecal streptococci) to determine the microbial quality of the groundwater and the relationship between the distances of the wells to latrines. Geographic Information System (GIS) tools were used to demonstrate spatial relationships for a better understanding of problems and possible solutions.

\section{Methods}

\subsection{Data Collection}

Both primary and secondary data were collected using two-stage approach. Collection of data from Primary Health Centres (PHC) for identifying the pattern of water-borne diseases was done in the first stage. Household questionnaire survey was conducted to identify water sources, water handling and other related information. Water sampling and analysis were carried out in the second stage. Data collection was done in a period of three months (March to May 2013). Based on the analysis of PHC data for the period of three months (March to May 2013), three residential areas that recorded high incidence of water-borne diseases (West Chullikaparamba, East Chullikaparamba and Murathummoola) and another two areas with low incidence (Kodiyathur and Karakutty) were randomly selected as study sites for household survey and water sampling. A well-structured questionnaire was designed to collect information on water sourcing, utilization, water handling and storage as well as ailments commonly experienced by the residents. Questionnaire survey was conducted based on the population of each area that is 10 residents were selected from areas with over 350 houses. In all, 50 respondents were selected from 50 houses drawn from five residential areas.

\subsection{Study Area}

Samples were collected from the Kodiyathur, which is a village in Kozhikode district in the state of Kerala, India of which is located on latitude $11^{\circ} 17^{\prime} 0 " \mathrm{~N}$ and longitude $75^{\circ} 59^{\prime} 0^{\prime \prime} \mathrm{E}$. It consists of about 15 wards (Figure 1 ). Among them five wards were selected for the current study. Kodiyathur is surrounded by two rivers, Chaliyar and Iruvazhinji. As of 2001 India census, Kodiyathur had a population of 26,429 with 13,136 males and 13,293 females making it densely populated.

\subsection{Spatial Mapping and Analysis}

Houses, groundwater wells and latrines in the selected wards of the village were mapped using a hand-held Global Positioning System (GPS) received Garmin GPS V (GARMIN International Inc., Kansas, USA). The GPS points were then taken down into excel sheets along with the attribute data for sampling stations. They were then plotted on a geo reference base map derived from an available recent toposheet. All these were done using open source GIS software from a Quantum GIS (QGIS 1.8.0).

\subsection{Sample Collection}

A total of fifty $(n=50)$ groundwater samples with replicates were collected from wells for bacteriological analysis. The samples were collected from five wards of Kodiyathur Village and the samples drawn aseptically were transferred to $10 \mathrm{ml}$ sterile bottles and properly labeled. Two samples each were collected from each well after which they were transported to the laboratory in ice cold condition and subjected to bacteriological analysis on the same day. The wells and latrines locations were determined using the Global Positioning System (GPS) device. A tape rule was used in measuring the distances between the latrines and wells. 


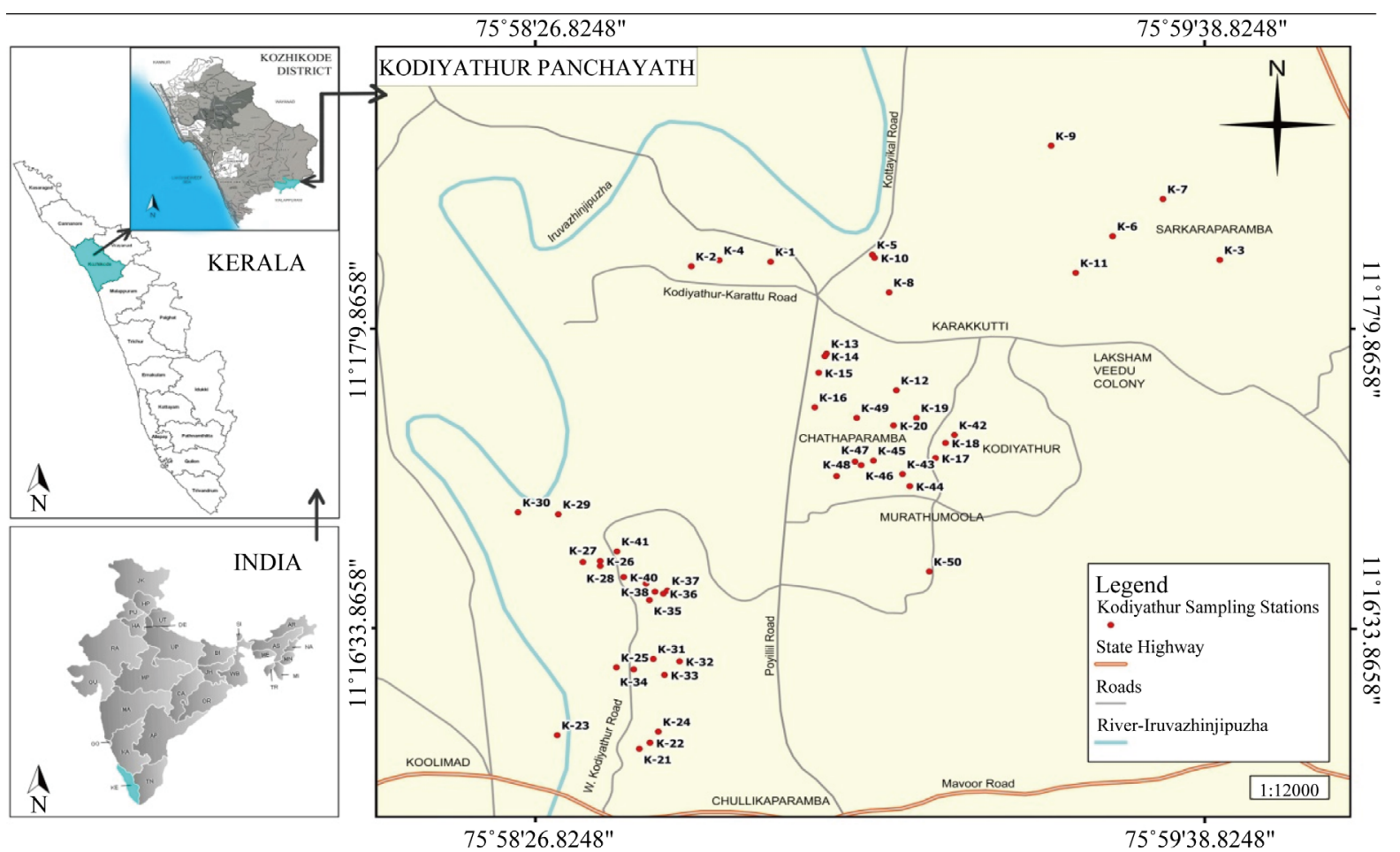

Figure 1. Map of study area showing sampling locations.

\subsection{Laboratory Investigation}

The Most Probable Number (MPN) test was used to enumerate the total number of bacteria in the well water samples. All the media used in this study were prepared and sterilized according to manufacturer's instructions. The bacteria determined included total coliform count (TCC), fecal coliform count (FCC), E. coli and fecal streptococci count (FSC). The parameters were determined using standard method for water analysis [18]. Total coliform, fecal coliform and fecal streptococci counts were estimated and recorded in Most Probable Number units per $100 \mathrm{ml}$ (MPN/100ml). Mean log MPN/100ml of replicates for the counts were also determined [19].

\subsection{Statistical Analysis}

The data obtained were analyzed with the aid of percentages and frequency tables while the t-test was used to compare the covered and uncovered wells. A correlation analysis was also carried out to establish the degree of relationship between the counts and the distances between the latrines and wells. The Statistical Package for Social Sciences (SPSS version 19.0) was used for the statistical analysis.

\section{Results}

Among the households which were surveyed, more than $95 \%$ of the residents sampled in the study area depend on open wells for domestic purposes. Bore wells ranked as the second major source of domestic water (5\%). Of the several problems encountered by residents, water sources drying up due to onset of dry season was $56 \%$. The use of common cup to draw water from pots situated strategically within the house was largely practiced by $60 \%$ of the residents. Common method of water treatment adopted by respondents included boiling (52\%), chlorination (24\%) and filtration (2\%). Primary Health Centre data showed that Acute Diarrheal Dysentery (56\%) was the most commonly reported water-borne disease, followed by Hepatitis (24\%). A total of $70.6 \%$ of the residents reported to have various water borne diseases had a well to latrine distance between 4 - 6 meters (Table 1).

It was observed that all the water samples collected were contaminated with total coliforms, fecal coliforms and fecal streptococci. Of the fifty wells analyzed, $68 \%$ of the wells reported high count of $E$. coli. The mean microbial counts obtained were high ranging from $<1.00$ to $3.38 \log$ MPN/100mL for TCC, FCC and FSC. Of 
Table 1. Percentage profile of water borne diseases and distances of latrine from wells in the selected wards during the period of March to May 2013.

\begin{tabular}{ccccc}
\hline Latrine Distance (m) & $\begin{array}{c}\text { ADD (Acute Diarrheal } \\
\text { Dysentery) }\end{array}$ & Hepatitis & Total & Percentage (\%) \\
\hline $4-6$ & 18 & 6 & 24 & 70.6 \\
$7-9$ & 3 & 1 & 4 & 11.8 \\
$10-12$ & 2 & 1 & 3 & 8.8 \\
$13-15$ & 2 & 1 & 3 & 8.8 \\
Total & 25 & 9 & 34 & 100 \\
\hline
\end{tabular}

the fifty well, 34 (68\%) were found to have the presence of E. coli (Figure 2). The distance of the wells to the latrines averages $6.44 \pm 2.37 \mathrm{~m}$. Virtually in all the wells sampled, the total coliform and fecal coliform counts were higher than the fecal streptococcal counts. Table 2 gives the log mean values of TCC, FCC and FSC of different well types and their distances to latrines. There was a moderate negative correlation $(\mathrm{r}=-0.593, \mathrm{r}=$ $-0.470)$ with a significant $(p<0.01)$ value between the distances from latrines and the coliform counts. In this study a strong positive correlation $(\mathrm{r}=0.608)$ between TCC and FCC, at $p<0.01$ was observed.

The sanitation and groundwater quality of Kodiyathur village was spatially represented and analyzed in the form of sanitation maps. Distribution of the bacteria and the distance between the well and latrine are the 2 major criteria used for defining the sanitation maps. The point feature map (Figure 3) displays the distance between the well and latrine of each sampling site. The distribution of total coliform, fecal coliform and fecal streptococi bacteria was represented through interpolated GIS maps that are processed by the Inverse Distance Weighting (IDW) method. This is a deterministic method used to differentiate the values at scattered points by assigning unique color ranges to each set of values. The map showing the distribution of fecal coliform count (Figure 4), represents that $30 \%$ of the total 50 water samples analyzed were contaminated with a very high count of faecal coliform count $(\geq 2400)$. The sanitation map for the distribution of fecal streptococci count (Figure 5), shows that $36 \%$ of the total 50 water samples analyzed were highly contaminated with fecal streptococci count $(\geq 2400)$. In comparison to the other two maps, majority of the samples were contaminated with total coliform bacteria in the sanitation distribution map of total coliforms (Figure 6). It is clear that $2 \%$ of the samples were with zero contamination.

Among the fifty wells studied, 32 wells were covered and maintained in good condition. A statistical significant difference $(p<0.01)$ was observed between the average distance of the wells from latrine and the TCC for the covered and uncovered wells, were there is a significant change in the mean TCC from $2.37 \pm 0.87$ to $3.28 \pm$ 0.16 in the covered and uncovered wells. Whereas there was no significant difference $(p<0.05)$ between the average distance of the wells from latrine and the fecal coliform and fecal streptococci counts for covered and uncovered wells (Table 3).

\section{Discussion}

The use of GIS tools to derive information about a community with regard to their environment is a useful technology which can be used for public health [20]. GIS maps have an advantage over traditional hand drawn maps since it is possible to integrate environmental attributes such as slopes and soil into a single visual representation by the layering technique [21]. In the present study, in the interpolated maps, contaminated sites are marked as red buffer zones. Only $2 \%$ of the samples were with zero contamination. The area marked in white that is the sample station K-8 was deprived of any bacterial contamination and was found to have improved sanitation status with proper waste management and higher distance between the latrine and well. The areas that are slightly contaminated are marked in blue to bluish green color and the red and orange shades in the map showed a high rate of TCC, FCC and FSC in the water samples.

In the point feature map (Figure 3) the red dots denotes wells of less than $7 \mathrm{~m}$ distance from latrines. This can be considered as an important criterion that explains the detection of coliform bacteria in those samples. The blue triangle in the map shows that the households maintained a decent distance of 7 to $10 \mathrm{~m}$ for their latrine and well. The green star indicates more than $10 \mathrm{~m}$ of distance between the latrine and well. This clearly explains to the reason why the sample K-8 showed zero contamination of coliform bacteria. Although, it is only one of the 


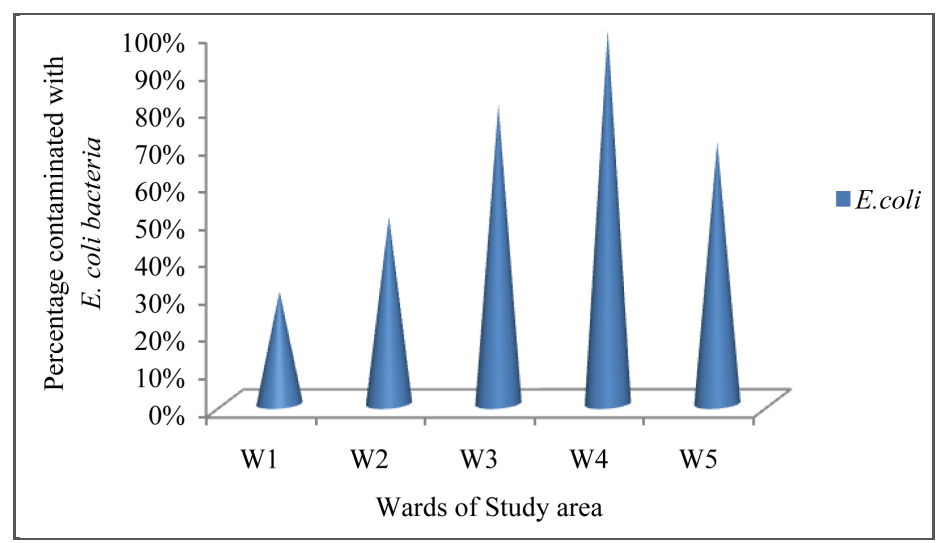

Figure 2. Percentage profile of $E$. coli in various wards of Kodiyathur Village.

Table 2. Correlation analysis on latrine distance and bacterial count.

\begin{tabular}{|c|c|c|c|c|}
\hline & & Distance from Latrine & Total Coliforms & Fecal Coliforms \\
\hline Distance from Latrine & Pearson Correlation & 1 & $-0.593^{* *}$ & $-0.470^{* *}$ \\
\hline Total Coliforms & Pearson Correlation & $-0.593^{* *}$ & 1 & $0.608^{* *}$ \\
\hline Fecal Coliforms & Pearson Correlation & $-0.470^{* *}$ & $0.608^{* *}$ & 1 \\
\hline
\end{tabular}

${ }^{* *}$ Correlation is significant at 0.01 level (2-tailed). ${ }^{*}$ Correlation is significant at 0.05 level (2-tailed).

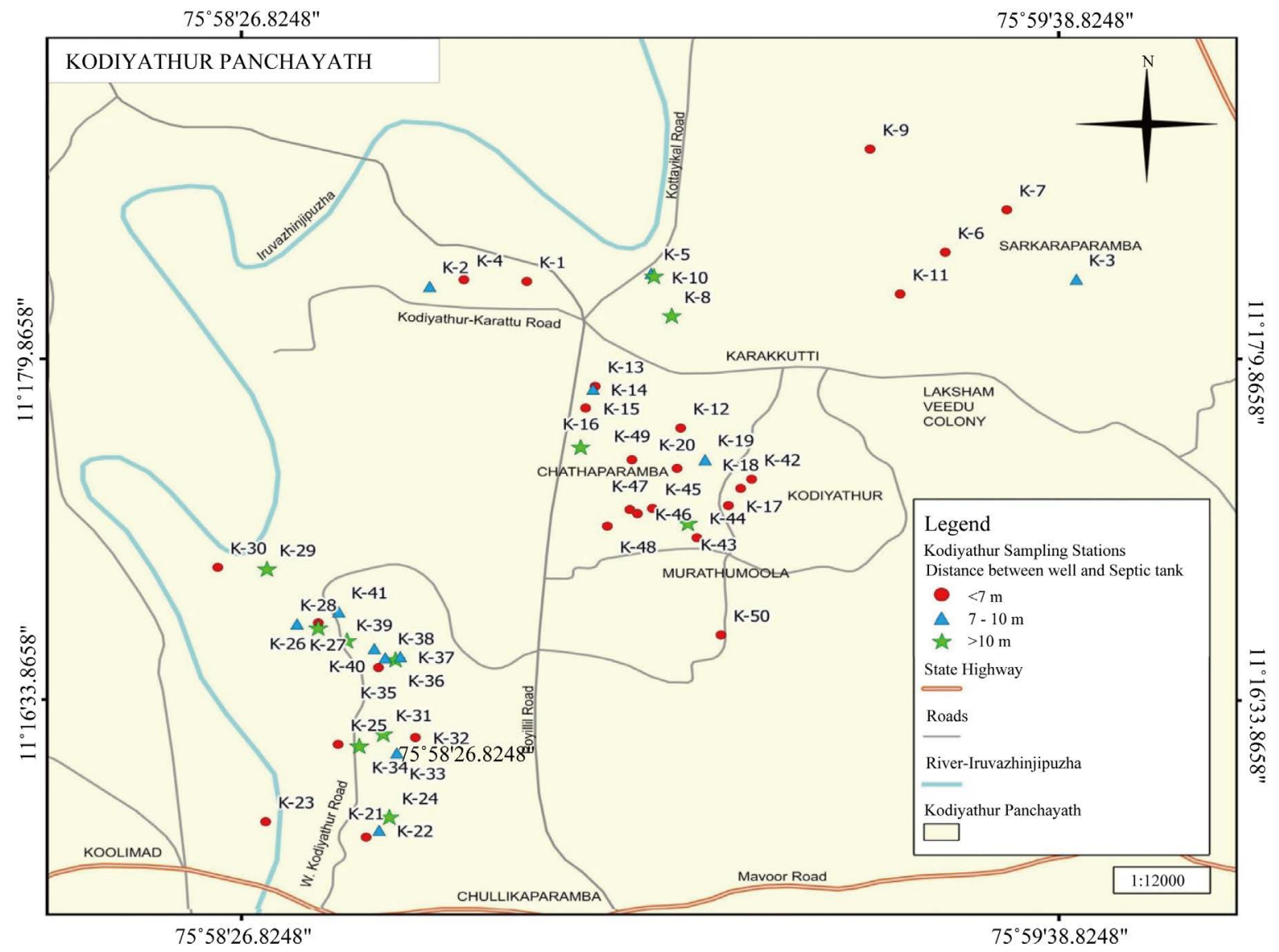

Figure 3. Point feature map of study area displaying the well to latrine distance. 


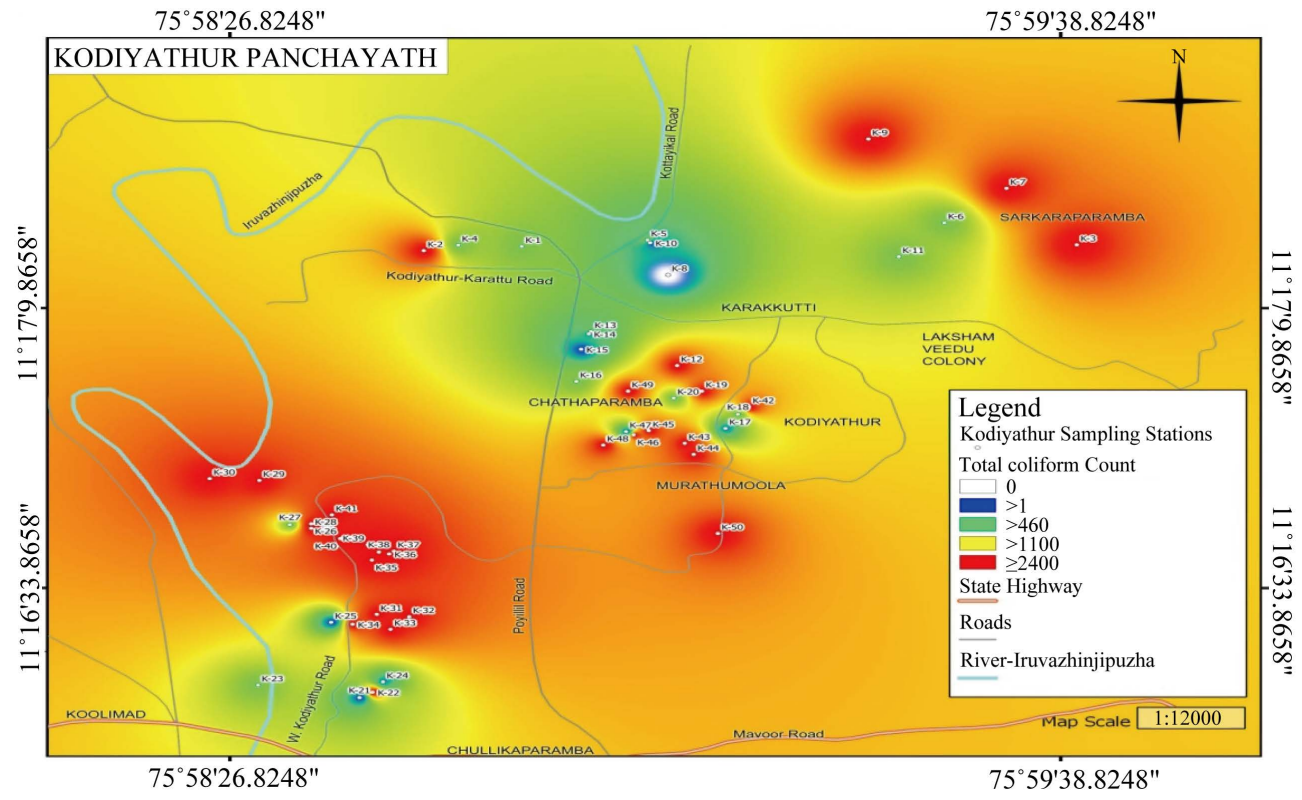

Figure 4. GIS map of study area with fecal coliform distribution.

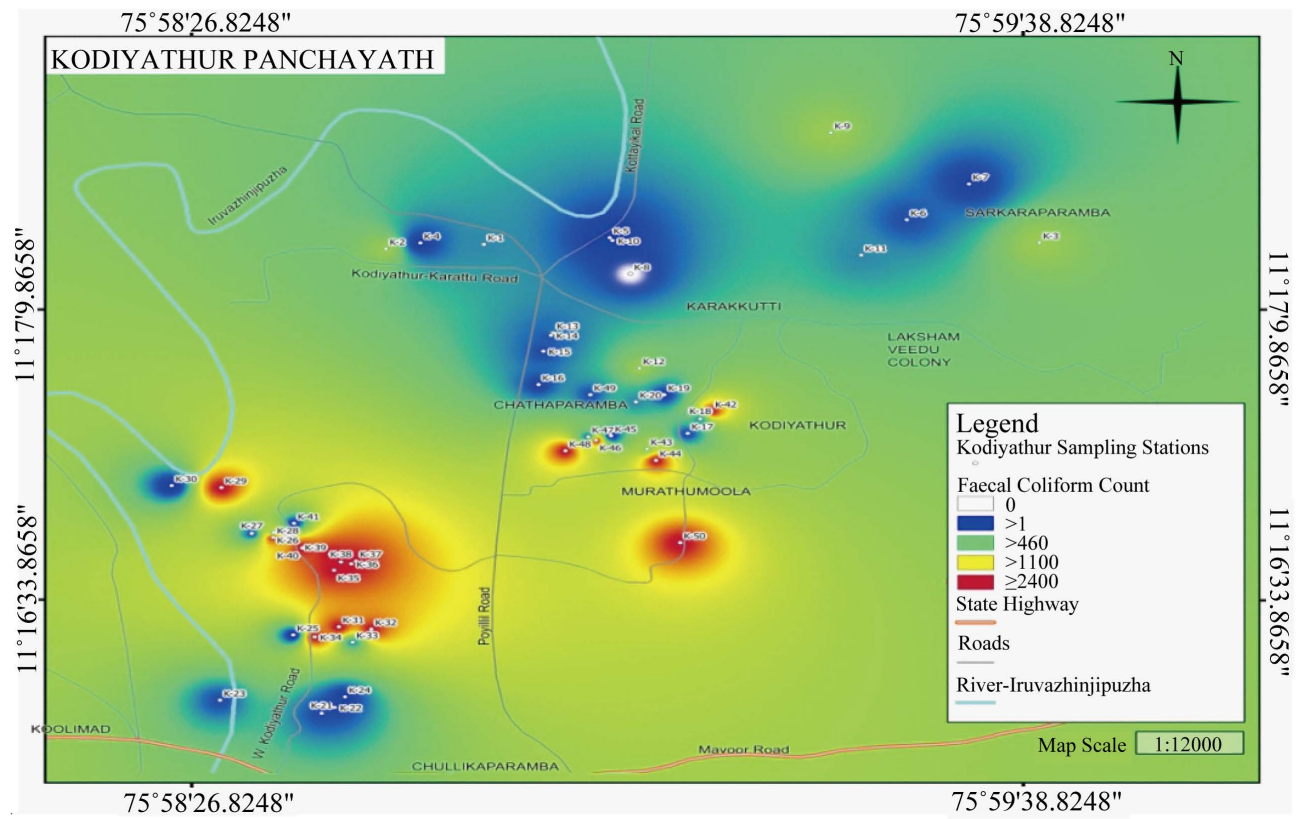

Figure 5. GIS map of study area with fecal streptococci distribution.

many criteria that define the sanitation status of an area.

High prevalence of Acute Diarrheal Disease (ADD) in the study area correlates with the presence of E. coli, which is one of the infective agents of ADD. The overwhelming dependence of residents on private wells showed the gross inadequacy of public water supply in the study area. Very few respondents considered the quality of water sourced at various locations a serious problem. Problems commonly identified by the residents were more related to the water source drying up. Lack of protection and control over management of water sources are indication of contamination risks [22]. Moreover, it is noteworthy that the popular water treatment methods adopted by the residents are not effective enough to eliminate several microbial contaminants [23].

The results of bacteriological analysis of well water from Kodiyathur Village showed that all the wells were 


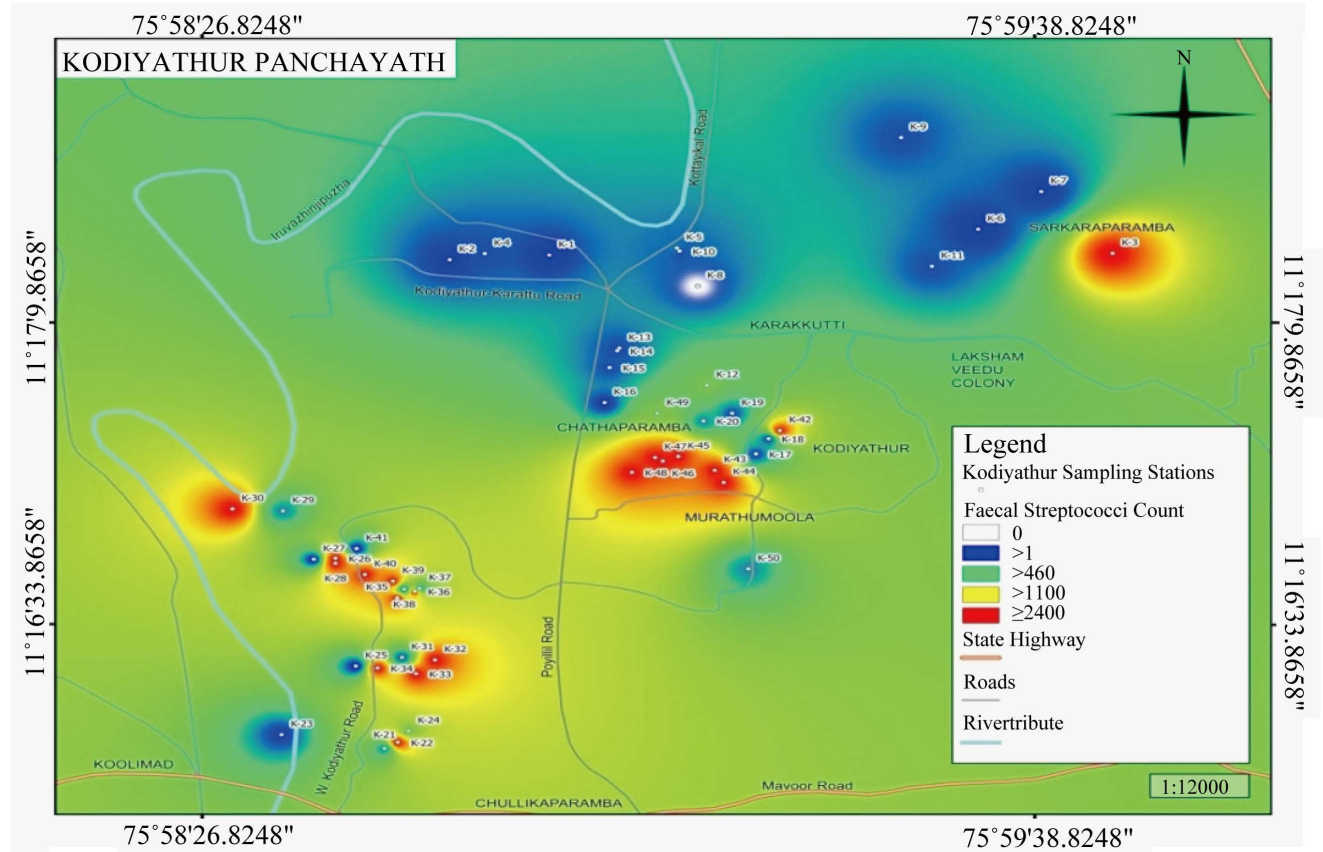

Figure 6. GIS map of study area with total coliform distribution.

Table 3. Mean log values of TCC, FCC and FSC of covered and uncovered wells and their distances to latrines.

\begin{tabular}{|ccccccc}
\hline $\begin{array}{c}\text { Number and type } \\
\text { of well }\end{array}$ & $\begin{array}{c}\text { Distance from } \\
\text { latrine }\end{array}$ & $\begin{array}{c}\text { Distance from } \\
\text { latrine }(\mathbf{m}) \\
\text { (USEPA Standard) }\end{array}$ & $\begin{array}{c}\text { Mean TCC } \pm \\
\text { standard deviation } \\
\text { of mean }\end{array}$ & $\begin{array}{c}\text { Mean FCC } \pm \\
\text { standard } \\
\text { deviation of mean }\end{array}$ & $\begin{array}{c}\text { Mean FSC } \pm \\
\text { standard deviation } \\
\text { of mean }\end{array}$ & $\begin{array}{c}\text { WHO/USEPA } \\
\text { standard for } \\
\text { the counts (/ml) }\end{array}$ \\
\hline Covered (32) & $9.90 \pm 2.726$ & 15.24 & $2.37 \pm 0.87$ & $2.02 \pm 0.74$ & $2.06 \pm 0.91$ & 0.0 \\
Uncovered (18) & $5.58 \pm 1.217$ & 15.24 & $3.28 \pm 0.16$ & $2.72 \pm 0.65$ & $2.73 \pm 0.85$ & 0.0 \\
\hline
\end{tabular}

contaminated with coliforms and other bacteria. Mean total coliform count, fecal coliform count and fecal streptococcal counts were high with the total coliform counts being higher. The high incidence of $E$. coli might have arisen due to the poor level of hygiene and sanitation observed in this Village. Wells in this area are constantly exposed to contamination from human activities. Also, the layout of the houses is not well planned such that the distances between wells and latrines and even refuse dumps are very minimal. In the studies conducted in Kozhikode district, [24] reported higher percentage of total coliform, fecal coliform and E. coli counts in various groundwater wells. These are in sharp contrast with [25] and [14] standards that stated that total coliform bacteria must not be detectable in any $100 \mathrm{ml}$ of water meant for drinking or for treated water entering distribution systems. These high parameters are of great concern to public health since the water from these wells is consumed by people without treatment [26]. The presence of coliform in water is an indication of feacal contamination and has been associated with waterborne epidemic [9]. Any water source used for drinking or cleaning purposes should not contain any organism of fecal origin [27].

The analysis of the relationship between bacterial indicator levels and environmental characteristics presents several statistical challenges [28]. The negative correlation obtained between the bacterial count and the distances to latrines connoted that the total bacteria load in the groundwater wells would decrease with increase in distance. A strong relationship between two indicators may provide some evidence that both indicators originate from the same or similar contamination sources [29]. Due to the complex nature of fecal coliform destination and transport, empirical methods such as regression models are unable to build up reliable load-concentration relationships [28].

The covered and uncovered wells demonstrated high bacterial counts, which might have possibly originated from environmental factors. Covering a well without maintaining a good level of environmental hygiene will lead to contamination of groundwater, though covered wells had low mean total coliform counts $(2.37 \pm 0.87$ 
$\log \mathrm{MPN} / \mathrm{ml}$ ), which possibly may be as a result of the protection in the form of grilled covering and it equally signified that there is a level of restricted access to these wells. Also, if the number of people accessing a particular well is more, there is a high degree of it being contaminated. In a field survey reported by [30], only about $18.7 \%$ of local residents in a part of the country clean their wells once every year. Dirty environments easily breed microorganisms. This is in agreement with the fact that coliform bacteria are widely found in nature [31] [32]. Poor town planning, dilapidated infrastructure and indiscriminate siting of wells and bore wells contributed to the low bacteriological quality of domestic water supplies, while rainfall can accentuate the impact [33].

[17] suggested that the most important factors affecting well vulnerability to bacterial contamination are those related to the well itself: construction and site management while it usage and maintenance are also crucial. However, concentrations of microbiological contamination indicator organisms observed in groundwater are a function of the contamination sources active at that moment [34]. These further explain why no significant difference was observed between the fecal coliform and fecal streptococcal count with respect to covered and uncovered wells.

The distances of the wells from latrines recorded in this study average to $6.44 \pm 2.37 \mathrm{~m}$. At this distance, TCC, FCC and FSC average are $3.21 \pm 0.23 \log$ MPN/100ml, $3.02 \pm 0.50 \log$ MPN/100ml and $2.86 \pm 0.26 \log$ MPN/100ml which contradict the USEPA/WHO standards. According to the earlier legislation which prevailed in the Kerala State, the minimum distance between dug wells and septic system was $15 \mathrm{~m}$, which underlines the importance of a sufficient soil-path length in contaminant removal. But as per the revised Kerala Municipality Building Rules 1999, the distance was made to be $7.5 \mathrm{~m}$. The minimum standard distance set by the USEPA/

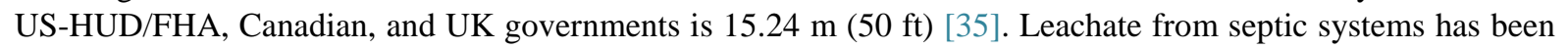
identified as a major potential source of groundwater contamination from pathogens such as bacteria, viruses, helminths, and protozoa, nutrients (nitrogen, phosphorus) etc. [36] [37]. Coliforms could travel through a distance of $70.7 \mathrm{~m}$ (232 ft) from sewage trenches intersecting groundwater, while traveling through sand and gravel aquifer in $35 \mathrm{~h}$ will cover $30.5 \mathrm{~m}$ (100 ft) from primary sewage injected subsurface [38]. Presence of septic systems and well depth were found to be related to detection of coliforms in groundwater, although these relationships were not statistically significant [29]. Effect of distance from pollution sources was more pronounced on fecal and total coliform counts, which decreased with increasing distance from waste dumps and defecation site [39].

It was also recorded that a high bacterial count was observed in the wells were the latrine distance $>10 \mathrm{~m}$, and the houses were higher incidents of water borne infections were reported also had a latrine to well distance between 4 - $6 \mathrm{~m}$. These results were consistent with the findings of [40] who recorded high bacterial counts in well at $3 \mathrm{~m}$ from drainage effluent and well in a residence house at $2 \mathrm{~m}$ from pit latrine and $2 \mathrm{~m}$ from refuse dump. The dense population of Kodiyathur Village could also be a major factor responsible for the high counts observed. [41] have shown that bacteria contaminate well water, depending on location. Also other factors such as, the environment where the well was situated and the level of hygiene of the well; in terms of the use of drawers and the population of people the well is serving and its surroundings could be considered as other possible sources of contamination aside the latrines. A cumulative increase in use of the wells over and above the latrines/latrines might lead to failure of the latrine system. This can increase the risk of contaminants entering drinking water sources. The river that is flowing through Kodiyathur Village is a potential source of contamination for the wells. Waste materials are disposed in the river, thus increasing the level of well contamination. About $5 \%$ of 50 wells sampled in Kodiyathur, were neither located close to latrines which explains the contamination through the river.

Standards regarding latrine placement should be reviewed if there be any at all. This can be achieved by imposing minimum lot size requirements larger than those which have been found to be associated with groundwater contamination. Another method is to evaluate each potential site individually taking into consideration of the geological characteristics of the site and methods of waste disposal being practiced in the area. A third approach could be to calculate the amount of dilution of effluent that is required before it reaches the groundwater to minimize the pollution potential. All this should be considered critically for further studies.

\section{Conclusion}

In conclusion, the findings of this study points to the fact that water sourced from wells in different parts of the study area, are not fit for drinking. Results of this study are significant because, a large population of people in 
the area of survey rely on latrines and wells. Therefore residents may be at risk of suffering from water borne illnesses after consumption of water without treatment. In this study, most of the observations made were supplemented with GIS maps which were helpful in identifying potential risks. In addition, the study also indicates that present distances between wells and latrines coupled with the level of hygiene of these wells are insufficient to prevent groundwater contamination. The problem of groundwater contamination via latrine is not an isolated problem of the area surveyed but rather a general problem hence precautions should be taken by setting standards for siting of wells from latrines and treatment of well water before use.

\section{References}

[1] Adekunle, A.S. (2008) Impacts of Industrial Effluent on Quality of Well Water within Asa Dam Industrial Estate, Ilorin, Nigeria. Nature and Science, 6, 1-5.

[2] Harikumar, P.S. (2009) Water Quality Status of Kerala with Special Reference to Drinking Water. 2009 Proceedings of Kerala Environment Congress, Thiruvnathapuram, 19-21 August 2009, 90-105.

[3] Mintz, E., Bartram, J., Lochery, P. and Wegelin, M. (2001) Not Just a Drop in the Bucket: Expanding Access to Point of Use Water Treatment Systems. American Journal of Public Health, 91, 1565-1570. http://dx.doi.org/10.2105/AJPH.91.10.1565

[4] Gerba, C.P., Rose, J.B. and Hass, C.N. (1996) A Sensitive Population: Who Is at Risk. International Journal of Food Microbiology, 30, 113-123. http://dx.doi.org/10.1016/0168-1605(96)00996-8

[5] Adejuwon, J.O. and Mbuk, C.J. (2011) Biological and Physiochemical Properties of Shallow Wells in Ikorodu Town, Lagos Nigeria. Journal of Geology and Mining Research, 3, 161-168.

[6] Snow, N.D. (1894) The Pathology and Mode of Communication of Cholera. London Medical Gazette, 9, 745-753.

[7] Swerdlow, D.S. (1992) Water-Borne Transmission of Epidemic Cholera in Trujilo, Peru: Lessons for a Continent at Risk. Lancet, 340, 28-33. http://dx.doi.org/10.1016/0140-6736(92)92432-F

[8] Alonge, D.O. (2005) Textbook of Meat and Milk Hygiene. Farmcoe Press, Ibadan.

[9] Mackenzie, W.R., Schell, W.L., Blair, K.A. and Addiss, D.G. (1995) Massive Outbreak of Waterborne Cryptosporidium Infection in Milwaukee, Wiscousin: Recurrence of Illness and Risk of Secondary Transmission. Clinical Infectious Diseases, 1, 57-62. http://dx.doi.org/10.1093/clinids/21.1.57

[10] Simango, C., Dinolwe, J. and Rukure, G. (1992) Bacterial Contamination of Food and Household Stored Drinking Water in a Farm Working Community in Zimbabwe. Central Africa Journal of Medicine, 36, 143-148.

[11] Obi, O.L., Polgieter, N., Bessong, P.O. and Matsung, G. (2002) Assessment of the Microbial Quality of River Water Sources in Rural Venda Communities in South African. Water South Africa, 26, 287-292.

[12] Fenwick, A. (2006) Waterborne Infectious Disease—Could They Be Consigned to History. Science, 313, $1077-1061$. http://dx.doi.org/10.1126/science.1127184

[13] Bridgman, S.A., Robertson, R.M., Syed, Q. and Speed, N. (1995) Outbreak of Cryptosporidiosis Associated with a Disinfected Ground Water Supply. Epidemiology Infection, 115, 555-566. http://dx.doi.org/10.1017/S0950268800058726

[14] USEPA (2009) National Primary Drinking Water Regulations. EPA 816-F-09-004, Washington DC.

[15] Lin, C.Y., Abdullah, M.H., Musta, B., Aris, A.Z. and Praveena, S.M. (2010) Assessment of Selected Chemical and Microbial Parameters in Groundwater of Pulau Tiga, Sabah, Malaysia. Sains Malaysian, 39, 337-345.

[16] Bourne, A.C. (2001) Assessing the Contamination Risk of Private Well Water Supplies in Virginia. Master’s Thesis, The Virginia Polytechnic Institute and State University, Blacksburg.

[17] Valenzuela, M., Lagos, B., Claret, M., Mondaca, M.A., Pérez, C. and Parra, O. (2009) Fecal Contamination of Groundwater in a Small Rural Dry Land Watershed in Central Chile. Chilean Journal of Agricultural Research, 69, $235-243$. http://dx.doi.org/10.4067/S0718-58392009000200013

[18] APHA, AWWA and Water Environment Federation (2012) Standard Methods for the Examination of Water and Waste Water. 14th Edition, American Public Health Association, Washington DC, 9:110-9:112.

[19] Roe, D. and Cardinale, J.A. (2005) Evaluation of Microbial Community Structures and Coliform Persistence in the Alfred Waste Water Treatment Plant Reed Bed Sludge Treatment System.

[20] Riner, M.E., Cunningham, C. and Johnson, A. (2004) Public Health Education and Practice Using Geographic Information System Technology. Public Health Nursing, 21, 57-65. http://dx.doi.org/10.1111/j.1525-1446.2004.21108.x

[21] Scotch, M., Parmanto, B., Gadd, C.S. and Sharma, R.K. (2007) Exploring the Role of GIS during Community Health Assessment Problem Solving: Experiences of Public Health Professionals. International Journal of Health Geograph- 
ics, 5, 39. http://dx.doi.org/10.1186/1476-072X-5-39

[22] WHO (1997) Guidelines for Drinking Water Quality, 2nd Edition, Volume 3: Surveillance and Control of Community Supplies. World Health Organization, Geneva.

[23] Enger, E.D. and Smith, B.F. (2003) Environmental Science: A Study of Interrelationships. 8th Edition, McGraw Hill Higher Education, New York.

[24] Harikumar, P.S. and Chandran, M. (2013) Bacteriological Contamination of Groundwater Due to Onsite Sanitation Problem in Keraka State: A Case Study. International Journal of Life Sciences Biotechnology and Pharma Research, 2, 190-202.

[25] WHO (2008) Guidelines for Drinking-Water Quality, Third Edition, Incorporating the First and Second Addenda Volume 1, Recommendations. WHO, Geneva.

[26] Adekunle, I.M., Adetunji, M.T., Gbadebo, A.M. and Banjoko, O.B. (2007) Assessment of Groundwater Quality in a Typical Rural Settlement in Southwest Nigeria. International Journal of Environmental Research and Public Health, 4, 307-318. http://dx.doi.org/10.3390/ijerph200704040007

[27] Akeredolu, F.A. (1991) Setting Water Quality-Water Quality Standards for Nigeria. Proceedings of the First National Conference on Water Quality Monitoring and Status in Nigeria, Kaduna, 16-18 October 1991, 216-224.

[28] Bai, S. and Lung, W.S. (2006) Three-Dimensional Modeling of Fecal Coliform in the Tidal Basin and Washington Channel, Washington DC. Journal of Environmental Science and Health. Part A, Toxic/Hazardous Substances and Environmental Engineering, 41, 1327-1346. http://dx.doi.org/10.1080/10934520600656984

[29] Francy, D.S., Helsel, D.R. and Nally, R.A. (2000) Occurrence and Distribution of Microbiological Indicators in Groundwater and Stream Water. Water Environment Research, 72, 152-161. http://dx.doi.org/10.2175/106143000X137220

[30] Ojeifo, O.M. (2011) Assessment of Rain Water Harvesting Facilities in Esanland of Edo State, Nigeria. Journal of Human Ecology, 34, 7-16.

[31] Binnie, C., Kimber, M. and Smethrust, G. (2002) Basic Water Treatment. Royal Society of Chemistry, Cambridge.

[32] Griffiths, J.F., Welsberg, B.S. and McGee, D.C. (2003) Evaluation of Microbial Source Tracking Methods Using Mixed Feacal Sources in Aqueous Test Samples. Journal of Water and Health, 1, 141-151.

[33] Egwari, L. and Aboaba, O.O. (2002) Environmental Impact on the Bacteriological Quality of Domestic Water Supplies in Lagos, Nigeria. Revista de Saúde Pública, 36, 513-520. http://dx.doi.org/10.1590/S0034-89102002000400019

[34] Solo-Gabriele, H.M., Wolfert, M.A., Desmarais, T.R. and Palmer, C.J. (2000) Sources of Escherichia coli in a Coastal Subtropical Environment. Applied Environmental Microbiology, 66, 230-237. http://dx.doi.org/10.1128/AEM.66.1.230-237.2000

[35] Inspect APedia (2010) Online Table of Required Well Clearances: Distances between Drinking Water Wells and Septic Systems, Treated Soils, Farm Buildings \& Other Site Features. www.InspectAPedia.com/water/ClearancesWells.htm

[36] Gerba, C. and James, E. (2005) Sources of Pathogenic Micro-Organisms and Their Fate during Land Application of Wastes. Journal of Environmental Quality, 34, 42-48.

[37] Fong, T.T., Mansfield, L.S., Wilson, D.L., Schwab, D.J., Molloy, S.L. and Rose, J.B. (2007) Massive Microbiological Groundwater Contamination Associated with a Waterborne Outbreak in Lake Erie, South Bass Island, Ohio. Environmental Health Perspectives, 115, 856-863. http://dx.doi.org/10.1289/ehp.9430

[38] Crane, S.R. and Moore, J.A. (1984) Bacterial Pollution of Groundwater: A Review. Water, Air, and Soil Pollution, 22, 67-83. http://dx.doi.org/10.1007/BF00587465

[39] Adekunle, A.S. (2008) Impacts of Industrial Effluent on Quality of Well Water within Asa Dam Industrial Estate, Ilorin, Nigeria. Nature and Science, 6, 1-5.

[40] Chiroma, T.M., Ugheoke, B.I. and Patrick, D.O. (2007) Environmental Impact on the Quality of Water from Hand-Dug Wells in Yola Environs. Academic Direct, 10, 67-76.

[41] Shimizu, T.T.M., Kigotake, T.M. and Agatomo, H.N. (1980) Bacteria Contamination of Drinking Water from Wells in Miyazaki, Japan. Bulletin of the Faculty of Agriculture Miyazaki University, 21-28. 
Scientific Research Publishing (SCIRP) is one of the largest Open Access journal publishers. It is currently publishing more than 200 open access, online, peer-reviewed journals covering a wide range of academic disciplines. SCIRP serves the worldwide academic communities and contributes to the progress and application of science with its publication.

Other selected journals from SCIRP are listed as below. Submit your manuscript to us via either submit@scirp.org or Online Submission Portal.
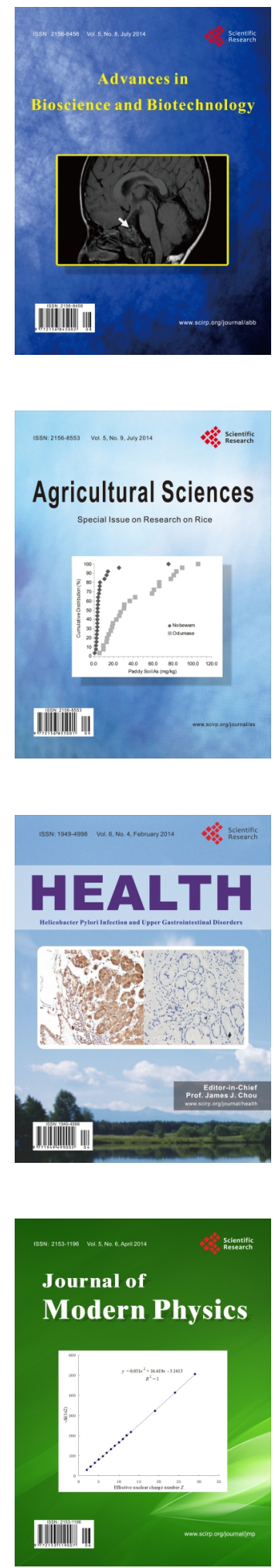
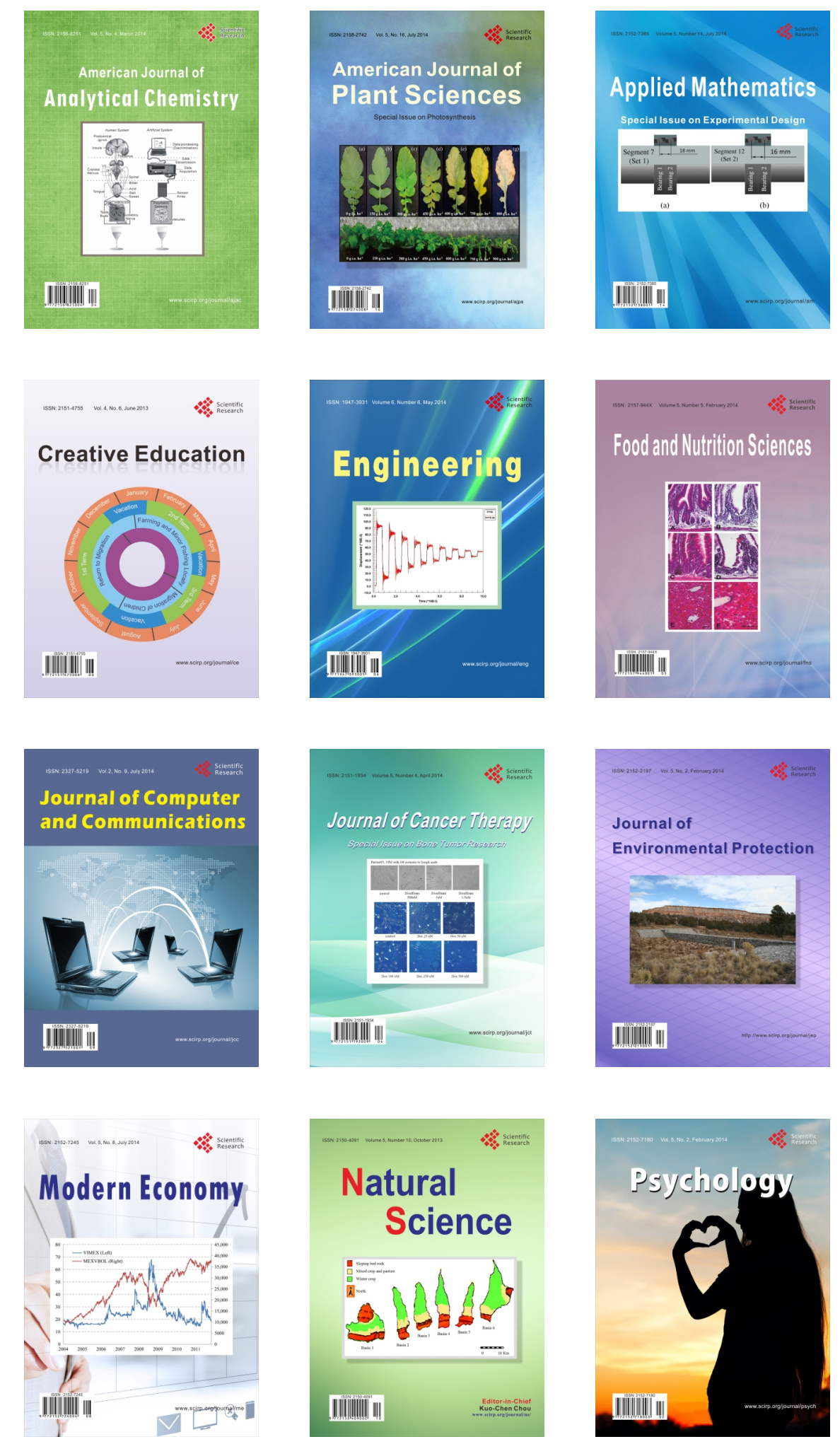